\title{
Mary-Claire King
}

From the early days of her graduate career to her forensic work in mass graves and recent research in the turbulent Middle East, Mary-Claire King has never been afraid to make waves. Her greatest accolade, however, is her enduring relationship with the families she has helped.

In the hallway outside geneticist Mary-Claire King's lab at the University of Washington in Seattle, amid rows of centrifuges and freezers, stands a rotating rack jammed full with postcards. This is no ordinary collection of a few old postcards from former lab members, tacked on with pins or faded tape. The hundreds of cards here come from countries all over the world-Argentina, Chile, Costa Rica, Guatemala, Croatia and Serbia, to name a few-and carry paeans of gratitude, affection and respect.

King has visited many of those places during more than two decades of work, using DNA to solve cases of human rights abuse and unraveling the genetics of complex diseases.

In the research community, King is perhaps best known for her 1990 discovery of the BRCA1 locus for hereditary breast cancer. Her announcement, after more than 16 years of work, electrified the field. Geneticists were skeptical that a complex disease such as breast cancer could be pinned to one gene, and few imagined the level of risk BRCA1 mutations confer-estimates now range from $60-80 \%$ worldwide and may be even higher, according to research now under way in King's lab.

"[The discovery] happened at a time that made [BRCA1] inevitably the point gene for a variety of conflicting situations," says King. Geneticists were just beginning to grapple with issues of patents, genetic discrimination and confidentiality. King's announcement set off a race to clone $B R C A 1$, which King ultimately lost to a group led by Mark Skolnik at Myriad Genetics. Myriad now has exclusive patent rights to $B R C A 1$ genetic tests in the US and elsewhere.

Kings says she is disappointed with the effects gene patenting has had on the development of new methods for genetic testing. "It is painful that lots of mutations in [BRCA1 and BRCA2] don't get found because the technology for finding them hasn't been fully worked out," she says. "There's no question [the patent] has constrained other testing schemes."

Since King's discovery, geneticists have linked several complex disorders, such as Alzheimer disease and prostate cancer, to a single mutation in a susceptibility gene. "Mary-Claire deserves credit for pioneering a paradigm that has held up for many diseases," says Maynard Olson, director of the University of Washington Genome Center. When King first began her work, people thought it was "foolish," adds Olson. "She changed the way human geneticists think of the interplay between complex diseases and Mendelian disorders.'

Even before her BRCA1 work, King was no stranger to the spotlight. In 1975, she made a splash with the results of her graduate work, reporting that humans and chimpanzees are $99 \%$ genetically identical. She is now an inspiration and a teacher to scientists who want to make a difference, says Olson. "[Young scientists], almost to a person, feel ambivalent about the monastic aspects of science, this withdrawal from the world of things they might feel most passionate about into this world of abstraction,” Olson says. “[King] provides a powerful counterexample.”

King's forensic work on mass graves has brought human rights violators to justice, most recently in the former Yugoslavia. She still continues work begun in 1984 with the 'Abuelas' - the grandmothers of the Plaza de Mayo in Buenos Aires-tracking children whose parents disappeared during Argentina's military dictatorship of the 1970s and early 1980s. Many of the children were left in orphanages or illegally adopted by military families. King's work reunites them with their grandparents.

The connection between her interests in science and in human rights is seamless, King says. "Some of the best science we ever did was in sorting out these human rights cases." The struggle to analyze DNA from only small samples in human rights cases, for example, inspired the concept of sequencing mitochondrial DNA from teeth to find genetic relationships.

King says she is interested in evolution, genetics and variation, and in exploring clinically important phenotypes. "I think as soon as you put all those elements together you are inevitably going to be working with people from all parts of the world," she says. "It is great fun to carry out genetics in a way that allows one to get to know families in these different environments."

Her interests have led her to tackle deafness, a disorder characterized by multiple genetic mutations. In 1997, based on research with a Costa Rican family, she and her collaborators cloned the first gene for nonsyndromic deafness. "I think that gave other people [in the deafness field] the road map for where they should be going," says Alan Ryan, a deafness expert at the University of California in San Diego.

"It is great fun to carry out genetics in a way that allows one to get to know families in these different environments."

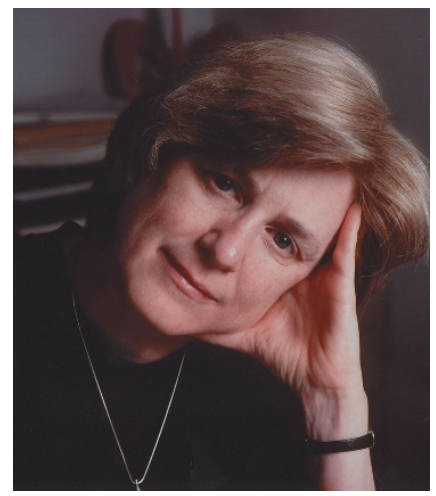

These days, King collaborates with researchers in two of the most volatile places on earth-Palestine and Israel. The team, which includes Karen Avraham at Tel Aviv University in Israel and Moien Kanaan at the University of Bethlehem in Palestine, has snagged a large grant from the US National Institutes of Health to track down genes for deafness.

In some villages of Palestine, up to $10 \%$ of the population is deaf, Kanaan says, making it an ideal place to investigate the disorder. "[King] is very concerned that the genetics of the people should be done by the people in that country," he says.

Despite the political situation in the Middle East, King has traveled to Palestine, most recently last year. "She looked at the damage the university took during the bombing of Bethlehem. She was there when nobody else was there," says Kanaan.

The collaboration is one of the only viable, strong scientific endeavors between Israel and Palestine. The new grant will enable the researchers to build the first sequencing facility in Palestine, allowing Palestinians to be screened for deafness in their own country. "By virtue of this collaboration, that to me is promoting peace," says Avraham. "That is Mary-Claire's way of doing it."

Charlotte Schubert, Seattle 